\title{
The meaning of the letter on the meaning in itself according to Ibn al-Nahas (d.698 AH)
}

\author{
Ahmed Yaqoub Hamid, College of Education / Wasit University department of Arabic language, \\ ahmdyqwbalmyahy@gmail.com \\ Prof. Mahmoud Hammoud Arak Al-Qurashi , College of Education / Wasit University department of \\ Arabic language
}

\author{
Abstract. The letter in the language : the edge, the margin, the side and the boundary \\ The letter : is the edge of something \\ The letter is everything : its side, its verge, and its boundary \\ In grammar a letter can be defined as : a word that refers to meaning \\ For example Alhamza for interrogative, ( from An) , (wish Layta), \\ ( May be Lala) and ( but Lakin ) called letters of meaning and grammarians in symbols of letters on the \\ meaning for Ibn Alnahas, the letter refers to the meaning of itself
}

Keywords: letter, meaning.

Received: 07.12.2020 Accepted: 13.01.2021 $\quad$ Published: 06.02.2021

\section{INTRODUCTION}

Ibn al-Nahas is Bahaa al-Din ibn al-Nahas Muhammed bin Ibrahim bin Muhammad bin Abi Nasr, the sheikh Imam Hajjat al-Arab Baha al-Din, Abu Abdullah bin al-Nahas, the grammatical Sheikh of alArabiyya, was born in the year( 627 Hijri). Al-Jawhari, he heard from Ibn al-Lati and al-Muwaffaq bin Yaish al-Nahawi, Abu al-Qasam Ibn Rawah, Ibn Khalil and his father, and he took Arabic on the authority of al-Jamal ibn Umarun.

And among its benefits is the perception of the wish and the rains. He has perfected the grammar and its conjugation, and he knew the extent of that, drew it and defined it, and he did not classify anything except what he dictated as an explanation of the book al-Muqrib, al-Muqarab, al-Mu'tiqa al-Wahwiyyah 1/1013, and looks at the year (698 AH). 1/317).

The grammarians agreed that the word has three parts, and this division comes from induction and reason which indicates that the word: (either a noun, verb, or letter) and there is no fourth for this triple division. (Introduction to rules explaining Tashail al-interest 1/136) To this, Abu al-Akbari (d. 616 AH) referred to this, and said: "It is only known that the word is only three on two sides, and one of them means meaning: the words and the meaning of the words are meaning: One of them to the other, so the expressions about it were (43) and the second was that they found these sections express every meaning that comes to mind in the soul, and if there had been a meaning for it, another section would have stood for it.

Then they defined the name as: "It does not indicate a meaning in itself that is an abstract sign of conjugation. It has characteristics such as the permissibility of attribution to it, the entry of the definition and preposition, as well as the tanun and addition. Al-Hajeb 2/836, and al-Kafiya in grammar 11)

The indication of individuation is present in the meaning of the name according to Ibn al-Sarraj (d. 316 $\mathrm{AH}$ ), so he said in his own right: "What indicates a singular meaning, and that meaning is a person and not a person. Concept, knowledge, day, night, and hour "(Al-Usul Al-Asoul Grammar 1/37)

As for the verb, they defined it as "that which is attributed to someone else and no one else is attributed to it" (Al-Labb fi Ailal Al-Building and Al-Arabiya 48/1).

Ibn al-Sarraj said: "The verb: denotes a meaning and a time, and that time is either past, present, or future." (Al-Usool fi Al-Grammar 1/38)

Or it "does not indicate a meaning in itself associated with one of the three times" (Explanation of Shazur al-Dhahab by Ibn Hisham 18).

As for the limit of the letter, they have agreed that "it does not indicate a meaning in other than it only" (the pulp in the ills of construction and syntax 50/2), and some of their phrases do not contain the word (only) as it will pass for us.

Perhaps the oldest text we received referring to this meaning is what Yaqoot and others narrated from the news of Imam Ali (peace be upon him) with Abi Al-Aswad Al-Dawali (d.69 AH) about the reason for 
setting the grammar, and what he gave in that newspaper to Abu Al-Aswad and what came in it "... in the name of Allah." The Compassionate, the Merciful, the word is all a noun, a verb and a letter.

It is nice to find Sebwayh (d.180 AH) expressing the letter that "it came to mean neither a noun nor a verb." When dividing the word into a noun, verb and letter, and represented for him by "then, sword, waw oath and lam addition" (see: Book 1/12)

Nevertheless, the difference in meaning between the letter and the corresponding noun and verb is unclear in the text of Sebwayh. (See: The Grammatical Research of the Fundamentalists 200)

Abu Al-Qasim Al-Zajaji (d. $337 \mathrm{AH}$ ) defined the letter as: "What denotes a meaning elsewhere, towards (from, to and then) and the like".

Al-Zujaji demonstrates a meaning: that it denotes a meaning in the other, even though the meaning of (from) on the surface indicates that it is an excuse in itself by saying: "(from) interferes with the speech of supplication. It was the goal of others, as well as all its faces.

Likewise (to) denotes the end, as it indicates the end of others, not its end itself, as well as all the letters of the meanings. "(The clarification in the ills of grammar 54-55)

Then he mentioned some of the grammarians 'definitions of the letter, that it is" without evidence of the noun and verb. "Others said:" The letter does not dispense with a sentence that it makes towards: No extra will come out, and the firstborn is not forthcoming, and that your brother is noticeable, and Muhammad is in the house. After it there is a noun, or a noun and a verb, or a noun and adverb.

And Ibn al-Warraq (d. $381 \mathrm{AH}$ ) continued the majority, saying: "As for the letter, it is considered to be a meaning that indicates a meaning in another, as for your saying: I took a dirham of money and extra money, so (from) an intervention of money. By omitting the noun and verb term from it, or by abstaining from its properties. (Faults of Grammar 142)

And Ibn Jinni (d. 392 AH) said: "The letter is a sign of noun and noun markings in which no Arabic word is not good, and no verb signs.

Al-Zamakhshari (d.538 AH) stated that the letter "does not indicate a meaning in others". (Detailed 384), and that it does not dispense with a noun or verb that accompanies it, that is, that it "does not indicate a meaning except in others, so it needs what is with him in order for his meaning to be useful in it." And they may separate from it i.e.: the noun and the verb in specific places in which the verb is omitted (articulated 384), and the letter suffices, so the constant passes, and if it is said: Did more come out? So I said: Yes, so it means: Yes, more came out. This benefit achieved is not from the letter, but rather is obtained from estimating the omitted, as we have explained.

Ibn al-Hajib (d. $646 \mathrm{AH}$ ) objected to him for limiting the deletion to the verb only, and he mentioned that there are places in which the noun is deleted, as well as there are places where the verb is deleted and that "making the omitted verb only is not straight" (See: Amali Ibn al-Hajeb 1/354).

Al-Suhaili ( $d$. And the letter had to be a factor in everything that indicated a meaning in it, because the words were subordinate to the meanings, just as the letter clung to what it entered into a meaning, so it was necessary to cling to it verbally, and that is action ..."(Results of al-Fikr 59).

Objected to Ibn Hisham (d. $761 \mathrm{AH}$ ) on the definition of grammarians character, he said: "The words of many grammarians crafts what is indicated on the meaning in other Vmentqd the names of the condition and the names of the question and the right to say what is indicated on the meaning of the others only, he said Gizouli and other investigators" (Pathological detective letter 34).

This is a select group of the sayings of the grammarians in which we have seen them that they are unanimously agreed that the letter has no meaning except in others, and al-Suyuti also mentioned that (d.911 AH) when he said: "What we have mentioned about that the letter does not indicate a meaning in the two words. 1/8)

Sheikh Baha al-Din ibn al-Nahas (d.698 AH) disagreed with them in this and violated their consensus. He claimed that the letter has a meaning in himself, and his evidence is that the person addressed by (does) for example understands the meaning of the interrogation. Because he knows that (is) placed in the origin of the language for interrogation, and also (perhaps) is placed for enjoining and (lest) for wishful thinking, as well as the rest of the letters, because he understands that depending on his understanding of his language (Hama al-Hawamah 1/8).

Ibn al-Nahas (698 AH) said in the commentary: "The other is for them to say: The letter is an expression indicating a meaning in other than it. The truth is that the letter has a meaning in itself.

The copper - as is clear from his words - believes that the letter has a meaning in himself, and his evidence is that the person addressed by (does) understands from it the meaning of the interrogation. Because he knows that (is) placed in the origin of the language for interrogation, and also (perhaps) is placed for enjoining and (might) for wishful thinking, as well as the rest of the letters, because he understands that depending on his understanding of his language. 
Then explain the difference between the meaning of a noun and a verb, and the meaning of the letter, for the noun and verb are understood before the syntax, that is, before they are combined in a useful sentence, for example: (Muhammad) is understood from it the person named by this name stripped of time, and so (get up), an example from which it is understood. The verb associated with the past tense, unlike the letter whose meaning is completed in the combination of it in the case of the singular.

And he was followed by his student Abu Hayyan (d.745 AH) in his book (Appendix and Complementation), and that was mentioned by Ibn Hisham (d.761 AH) (see: Explanation of the Badriya Al-Mihrah 250).

But it appears from the words of Abu Hayyan that he did not conclude that, and the subject in his opinion needs - as he said - a careful thought and consideration, and that is that the definition that the grammarians mentioned for the letter is not clear to him, because when they defined the letter they said, "The letter indicates a meaning in other than it".

The objection of Abu Hayyan may be due to the fact that the meaning of the letter may be understood by himself, and that comes to the mind of the scientist with the vocabulary of the language. Likewise, (does), the interrogation is understood from it, as it is understood from (hit) the past tense, and from the rubbish that its meaning is restriction, so it needs a clear distinguishing characteristic that distinguishes the meaning of the letter from the connotation of the name and the verb "(Appendix and Supplement 1/50)

And this one who made him choose the preponderant saying of the investigators that the letter indicates a meaning in others only, he said: "The best thing that was said in the end of the letter is:" The letter is a word indicating a meaning in others only. "(Appendix and Al-Takamul 1/50)

We see him commenting on his previous words by saying: Our saying (word) is gender includes the noun, verb and letter, and our saying: (sign) has a meaning in others as a precaution against the noun and verb. And our saying: (only) a precaution against the names of the condition and the interrogation, for they indicate meaning in others, but nonetheless they indicate a meaning in themselves "(Appendix and Supplemental 1/50).

What is meant by al-Nahas is from his saying: "The difference between them is that each one of the noun and verb is understood by it in the singularity that which is understood by it in the syntax other than the letter, because the meaning understood by the letter in the case of the composition is more complete than what is understood by it at the individual. "The word, if its meaning is fully understood by simply mentioning its word without enclosure, it is expressed that it has a meaning in itself, and if the full understanding of its meaning is dependent on an enclosure, then it is expressed that its meaning is elsewhere (Al-Jana Al-Dani 86, see: Al-Mufasel explanation by Ibn Yaish 4/447)

If we look closely, we find that the grammarians think that the perception of the meaning of the name and the verb in the mind is not dependent on something outside of them. If we say (Zaid), it indicates a meaning in itself without enclosing something else, or saying (sit) it indicates a meaning in itself. As for the perception of the meaning of the letter, it depends on the enclosure of another matter about it. The whole saying of the grammarians, "The meaning denoted by letters ... does not pronounce the letter, but rather does what the letter relates to in terms of nouns and verbs, so (from) indicates initiation and (will) to Procrastination and (may) on verification and (then) on relaxation and (fulfillment) in the order, but it is in the meanings of what these letters are related to in terms of the sentence and not in the same letter "(The Grammar Research of the Fundamentalists 202)

Dr. Mustafa Jamal al-Din believes that what Ibn al-Nahas went to "ends with the meaning of the letter, but at the same time it does not conclude that this meaning is independent of itself." He explains what he said that the meaning is of two types: an independent individual meaning, and an independent syntactic meaning, as for the independent singular meaning, which is the image that appears and forms in a person's mind, such as a picture of a wall or a horse, or starting when hearing the word alone, i.e.: outside the sentence or composition, whether It is known that there was a wording here or not for that meaning, but the benefit of his knowledge of the situation is that when he hears the word (mare), for example, that independent image is present in his mind, and this presence is independent and not by adding something else to it.

The syntactic meaning is: the meaning that does not appear in the mind in the case of the singular, but is present in the case of synthesis within a sentence and needs an external enclosure and the understanding of its meaning stops on that enclosure. (Muhammad) in the event that it is abstract and this meaning is not understood from it, and so in (Is) then it is a term from which only the meaning of the interrogation can be understood, but if it is installed then we said: (Did Muhammad stand up from it and he was understood?) It is a meaning that is not fulfilled in the case of the singular ', but is understood in the case of the synthesis, and the presence of an external enclosure. The Interrogation "(the grammatical research of the fundamentalists 202-205). 
And Jamal al-Din made (Is) and other letters of the second level, so for example, if we said (Did Muhammad rise) then we know that the resurrection of Muhammad is questioned from within the sentence and the synthesis, not from the word (is), for it alone is not understood from it, but rather The meaning of the interrogative is not understood in the singular; Because an interrogative image does not arise in a mind when hearing the word "do" alone. Unlike if we heard the interrogative word or interrogated, that is because the word (does) denotes the situation to special interrogations such as "the question about Muhammad standing up or Amr sitting, that is: it was placed to denote the interrogation in the event that it is (a synthetic meaning) and not to the absolute independent interrogation in its meaning, otherwise it would be a name. Synonymous with the word interrogative "(the grammatical research of the fundamentalists 202-205).

Then Sayyid Mustafa Jamal al-Din concludes that the letters do not indicate a meaning in themselves', weakening the article of Ibn al-Nahas [see: The Grammatical Research of the Fundamentalists 204-205.

It seems that Ibn al-Nahas and Abu Hayyan were greatly influenced by what was reported by Abu Ali alFarisi (d. $377 \mathrm{AH})$ and his problem with the predecessors 'definition of the letter in that it indicates a meaning in others. Abu Ali al-Farsi said, as quoted by Ibn Yaish (d.643 AH): "Abu Ali al-Farsi said: Whoever claims that the letter does not indicate a meaning in another, then the names of all the events must be letters, because they indicate meanings in others, and if he says: then the standing He is fancied alone by the Qaem, he was told: The affixing and the definition indicated by the traction and the knowledge blame may be deluded separately from the two names ... "(Al-Mufassal explanation by Ibn Yaish 4/448).

What is useful to mention here is that Mr. Alaa Bahr al-Uloom and other fundamentalists believe that alMohaqiq al-Radhi (d.686 AH) went to the opposite of what Ibn al-Nahhas said (see: Grammatical Research of the Fundamentalists 212, and from the experiences of the Fundamentalists 63) and Bahr alUloom described it as "in the limit of negligence" And that is because Al-Radhi said according to what he said: "The letters have no meaning in the first place, but rather they were brought into words in speech as a sign of a specificity in the place. Specificity in its income refers to it as efficacy and potency, as well as the letters ..." (Masabat al-Usul S1 / 69-70)

Many of the fundamentalists, among them the author of the gossip articles (see: The Syntactic Research of the Fundamentalists 212), attributed this opinion to the contentious investigator, but the phrase "satisfied" in explaining the adequacy is different from what was attributed to him, for he said: "The letter is a word that denotes a fixed meaning in others" (Sharh Al-Radi Ali Sufficient 1/27).

Elsewhere he said: "The meaning of" from "the beginning is the same, and the meaning of" from "and the meaning of the word" beginning "is the same, except that the difference between them is that the meaning of the word" initiation "is not the meaning of another word, but its meaning is its meaning which in itself is identical, and the meaning of (who) is the content of another word This content is added to the meaning of that original expression .... The letter alone has no meaning in the first place, as it is like a science attached to something to indicate that there is some benefit in that thing. (Explanation of Al-Radhi Ali Al-Kafiya 1/27).

Mr. Mustafa Jamal al-Din clarified this fact and pushed for what was attributed to Al-Radhi, saying: "They attributed to Al-Radi that he said:" The letter has no meaning in the first place. Rather, it is like a science attached to something to indicate that there is some benefit in it. Al-Radhi did not go to denying the meaning of the letter nor denying its connotation, but rather said: The letter is a word that indicates a fixed meaning in the pronouncement of others. The meaning of (from) and the meaning of the word "beginning" are the same, except that the difference between them is that the meaning of the word "initiation" is not the meaning of the meaning of another word .. and the meaning of "from" is the content of another word, so that content is added to the meaning of that original word. Al-Radi did not say: the letter has no meaning in the first place. As they attributed to him, but he said: The letter alone has no meaning in the first place. The word (alone), which constitutes a difference between his opinion and theirs, was deleted, and it was extracted from the text that they quoted from him, which clarifies this opinion ..." (The Grammar Research of the Fundamentalists 214-215).

Sayyid Muhammad Taqi al-Hakim discussed the authors of this opinion and transmitted the words of AlRidhi completely without deduction. Originally "(From the experiences of the fundamentalists 64).

And he saw that this delusion was caused by transmitting the text in an amputated manner, and that it was read separately from its predecessor, but if we put what they deleted in its proper place - as in the origin of the phrase al-Radhi - the illusion would have risen and another aspect appeared in the simile. Meaning that he thinks that its meaning exists in others, and the word has no independence in its connotation. If the letter is presented separately, its connotation will not be absent as science, so the similarity between it and science is clear of meaning when it is alone and not at all as its word declares it, so the letter alone has no meaning. That delusion "(from the experiences of the fundamentalists, 64). 
Then he asserted that saying "that the letter has no meaning and we do not know him saying it" (from the experiences of the fundamentalists in the linguistic fields 64)

\section{Conclusion: At the end of this research, the following results can be summarized:}

1- The research revealed that the definition of the letter according to many grammarians is "that which indicates a meaning in other than it," such as your saying: I took a dinar from Amr's money, then (from) an intervention to exchange money, and some is a dinar.

2 -The research proved that the previous definition of the letter is contradictory and contradicts the nouns of the conditional and the interstitial, because they also signify a meaning in others, and the right is to say that which indicates a meaning in other than it and only in the words As Abu Musa Al-Jazzouli, Ibn Hisham Al-Ansari, and other investigators said.

2- $\quad$ The study showed that Sheikh Ibn al-Nahas disagreed with the grammarians in that the letter did not indicate a meaning in itself and violated their consensus in that, so he claimed that the letter has a meaning in himself, and his evidence is that the person addressed by (does) for example understands the meaning of the interrogation. Because he knows that (is) placed in the origin of the language for interrogation, and also (perhaps) is placed for hope and (wish) for wishful thinking, as well as the rest of the letters, because he understands that depending on his understanding of his language.

3 -The study showed that Sheikh Ibn al-Nahas disagreed with the grammarians in that the letter did not indicate a meaning in itself and violated their consensus in that, so he claimed that the letter has a meaning in himself, and his evidence is that the person addressed by (does) for example understands the meaning of the interrogation. Because he knows that (is) placed in the origin of the language for interrogation, and also (perhaps) is placed for hope and (wish) for wishful thinking, as well as the rest of the letters, because he understands that depending on his understanding of his language.

-4 Dr. Mustafa Jamal al-Din went that what Ibn al-Nahas went to "ends with the meaning of the letter, but at the same time it does not conclude that this meaning is independent of itself." He explains what he said that meaning is of two types: a singular meaning that is independent, and a synthetic meaning that is not independent.

5 - The study found that letters do not indicate a meaning in themselves, because grammarians believe that "the perception of the meaning of the name and the verb in the mind is not dependent on something outside of them. It denotes a meaning in itself. As for the perception of the meaning of the letter, it is dependent on the enclosure of something else about it. The whole saying of the grammarians, "The meaning denoted by letters ... does not pronounce the letter, but rather does what the letter relates to in terms of nouns and verbs, so it is an indication (from ) To begin and (then) to relax and (faa) in the order, but it is in the meanings of what these letters are related to from the sentence terms and not in the same letter.

\section{References}

1.Fundamentals in grammar: Abu Bakr Muhammad bin Al-Suri bin Sahl, the grammarian known as Ibn Al-Sarraj (d. 316 AH), translated by: Dr. Abd Al-Hussein Al-Fattli, The Resala Foundation, Beirut, 3rd Edition, 1417 AH 1996 AD.

2 .Amali Ibn al-Hajib: Abu Amr Othman bin al-Hajib (d.646 AH), under the title: Dr. Fakhr Salih Suleiman Qadara, Dar Ammar - Jordan, Dar Al-Jeel, Beirut, 1409 AH - 1989 AD.

3 .Clarification of grammatical errors: Abu al-Qasim al-Zajaji (d. 337 AH), under: Dr. Zaki al-Mubarak, Dar al-Nafaes, Beirut, ed. 1, 1394 AH, 1974 CE, ed.6, 1416 AH - 1996 AD.

4 .Al-Kafiyyah in grammar: Ibn al-Hajib Jamal al-Din bin Uthman bin Omar bin Abi Bakr al-Masry al-Masri al-Maliki (d.646 AH), translated by: Dr. Saleh Abdel-Azim Al-Shaer, Literature Library - Cairo, 1st Edition, 2010

5 .The book: Abu Bishr Amr ibn Othman bin Qanbar al-Harthy al-Walaa, nicknamed Siwayh (d. $180 \mathrm{AH})$, under: Abd al-Salam Muhammad Harun, al-Khanji Library, Cairo, 3rd edition, 1408 AH - 1988 AD.

6 .The Grammatical Research of the Fundamentalists: Mustafa Jamal al-Din, Dar al-Hijrah, Qom, 2nd ed., $1405 \mathrm{AH}$.

7 .The surrounding sea in interpretation: Abu Hayyan Atheer al-Din Muhammad bin Yusuf bin Ali bin Yusef bin Hayyan al-Andalusi (d.745 AH), translated by Sadqi Muhammad Jamil, Dar al-Fikr, Beirut, $1420 \mathrm{AH}$.

8. In order for the devotees in the classes of linguists and grammarians: Jalal al-Din Abd al-Rahman alSuyuti (d. $911 \mathrm{AH}$ ), opened by: Muhammad Abu al-Fadl Ibrahim, Issa al-Babi al-Halabi and Co., ed. 1, 
1384 AH 1965 AD. Title: Dr. Mazen al-Mubarak, Dar Ibn Katheer - Damascus / Beirut 1st Edition, $1408 \mathrm{AH}-1987 \mathrm{AD}$

9. Appendix and supplement to explaining the book of facilitation: Abu Hayyan Al-Andalusi (d.654 -745 $\mathrm{AH}$ ), under: Dr. Hassan Hindawi, Treasures House of Seville for Publishing and Distribution, Riyadh, ed. 1, 1434 AH 2013 AD.

10. Commentary on al-Muqarab: Explanation of the Allama Ibn al-Nahas on Muqrib Ibn Asfour in Grammar, Under: Doctor: Jamil Abdullah Aweidah, Ministry of Culture, Amman, 1424 AH 2004 AD.

11. Preface the rules with an explanation of the facilitation of benefits: Muheb al-Din Muhammad bin Yusuf bin Ahmed, known as the Nazir of the Army (d. 778 AH), under: Dr. Ali Muhammad Fakher and others, Dar Al-Salam Press, Cairo, Edition 1, 1428 AH 2007 AD.

12. Explanation in detail on the work of the syntax marked by fermentation: Issued by the Honorable AlQasim Bin Al-Hussein Al-Khwarizmi, U: Dr. Abdul-Rahman Bin Sulaiman Al-Uthaimin, Dar Al-Gharb Al-Islami, Beirut, 1990.

13.Explanation of Al-Radhi Ali Al-Kafiyyah: Radhi Al-Din Al-Istrabadi (d.686 AH), investigation and commentary: Yusef Hassan Omar, Al-Sadiq Foundation for Printing and Publishing, Tehran, 1st Edition, 1398 BC-1978 AD.

14. Explanation of the shadows of gold in knowing the words of the Arabs: Abu Muhammad Jamal al-Din Abdullah bin Yusuf, known as Ibn Hisham the Nahawi (d.761 AH), chanted by: Muhammad Abu Fadl Ashour, House of Revival of Heritage, Beirut, 1 ed. 1422 AH 2001 AD.

15. Explanation of the Badriyah Glimpse in Arabic Linguistics: Dr. Hadi Nahr, Al-Yazouri Scientific House, Amman, 1394 AH - 1974 AD.

16. A detailed explanation by al-Zamakhshari: Abu al-Buqa 'Ya'ish ibn Ali ibn Ya'ish ibn Abi al-Saraya Muhammad bin Ali, Muwafaq al-Din al-Asadi al-Mawsili known as Ibn Yaish and Ibn al-San'a (d.643 $\mathrm{AH}$ ), presented to him by: Dr. Emil Badi Ya'qub, Dar Al-Kutub Al-Ulumiyyah, Beirut, 1 ed. 2001 A.D. 1422.

17. Syntax: Abu al-Hasan Muhammad bin Abdullah, Ibn al-Warraq (d. 381 AH), under: Mahmoud Jasim Muhammad al-Darwish, Al-Rushd Library, Riyadh, 1st Edition, 1420 AH - 1999 AD.

18. The pulp in the ills of construction and parsing: Abu Al-stay Abdullah bin Al-Hussein bin Abdullah AlAkbari Al-Baghdadi Moheb Al-Din (d. Abdul Ilah Al-Nabhan, Dar Al-Fikr, Damascus, 1st Edition, 1416 AH, 1995 AD.

19. Glosses in Arabic: Abu Al-Fath Othman Bin Jani (d. 392 AH), U: Dr. Samih Abu Mughali, Majdalawi House for Publishing, Amman 1988 AD.

20. Pathological investigations related to (from) the police: Abdullah bin Yusuf bin Ahmed bin Abdullah bin Yusuf, Abu Muhammad, Jamal al-Din, Ibn Hisham (d.761 AH), under: Mazen al-Mubarak, Dar Ibn Kathir - Damascus / Beirut, 1 ed. 1408 AH - 1987 AD.

21. Lamps of Assets: Mr. Aladdin Bahr Al-Ulum, Dar Al-Zahra, 3rd Edition, 1431 AH 2010

22. The Literary Dictionary = Guiding Al-Arib to Know the Writer =: Abu Abdullah Shihab al-Din Yaqut bin Abdullah al-Rumi al-Hamwi (d.626 AH), ed: Ihssan Abbas, Dar al-Gharb al-Islami, Beirut, 1st Edition, $1414 \mathrm{AH}-1993 \mathrm{AD}$

23. The detailed one on the work of the parsing: Abu al-Qasim al-Zamakhshari Mahmoud bin Omar bin Muhammad al-Khwarizmi (d.538 AH) under: Dr. Khaled Ismail Hassan, revised by Dr. Ramadan Abd al-Tawab, third edition, Literature Library, Cairo 2014.

24.From the experiences of the fundamentalists in the linguistic fields: Mr. Muhammad Taqi al-Hakim, International Foundation for Studies and Publishing, Beirut, 1st Edition, 1423 AH / 2002 AD

25. The results of thought in the grammar of Al-Suhaili: Abu Al-Qasim Abd Al-Rahman bin Abdullah AlSahili (d.581 AH), under the title: Sheikh Adel Ahmed Abdel-Mawgid, Sheikh Ali Muhammad Mawad, Dar Al-Kutub Al-'Almiyyah, Beirut, 1 ed.

26. Hama al-Hawam'i, Explanation of the Collection of Mosques: Jalal al-Din al-Suyuti (d. 911 AH), Tah: Professor Abd al-Salam Muhammad Harun and Doctor Abd al-Aal Salem Mukarram, The World of Books, 1421 AH 2001 CE.

27. Al-Wafi of the deaths: Salah al-Din Khalil bin Aybak bin Abdullah al-Safadi (d.764 AH), under: Ahmad al-Arna'out, Turki Mustafa, House of Revival of Heritage, ed. 1,1420 AH - 2000 AD . 